Vol. 17 (2008): 307-324.

\title{
Review article \\ Plant biotechnology for deeper understanding, wider use and further development of agricultural and horticultural crops
}

Paula Elomaa, Jussi J. Joensuu, Helena Korpelainen, Kristiina Mäkinen ${ }^{1}$, Viola Niklander-Teeri, Minna Pirhonen, Mervi M. Seppänen, Teemu H. Teeri and Jari P.T. Valkonen*

Department of Applied Biology, PO Box 27, FI-00014 University of Helsinki, Finland

${ }^{1}$ Current address: Department of Applied Chemistry and Microbiology, PO Box 27,

FI-00014 University of Helsinki, Finland,

*e-mail: jari.valkonen@helsinki.fi

\begin{abstract}
Plants bind solar energy to organic matter via photosynthesis and assimilation of carbon dioxide from the atmosphere and comprise the major source of nutrition and bioenergy. Plant biotechnology contributes to solution of important constraints in food and feed production and creates new technologies and applications for the sustainable use of plant resources. Genome-wide approaches such as massive parallel sequencing and microarrays to study gene expression, molecular markers for selection of important traits in breeding, characterization of genetic diversity with the aforementioned approaches, and somatic hybridization and genetic transformation are important tools in plant biotechnology. In this paper, studies carried out on enhanced resistance to viruses and tolerance of cold stress in potato, genetic modification of flower pigmentation and morphology in gerbera, production of edible vaccines in transgenic barley seeds, and expression of heterologous proteins for pharmaceutical purposes from vector viruses were chosen to exemplify the general utility of biotechnological approaches and also how plant biotechnology research has developed on cultivated plants at University of Helsinki. The studies reveal cellular and genetic mechanisms and provide scientific information that can be used for widening the uses of crop plants. They can also be used to detect any putative risks associated with the use of the biotechnological application in agriculture and horticulture and to develop practises which reduce any inadvertent negative consequences that plant production may have to the environment.
\end{abstract}

Key-words: plant biotechnology, molecular biology, crop production, horticulture, disease resistance, stress tolerance, metabolic pathway, biopharming, edible vaccine, cryotherapy 


\section{Elomaa, P. et al. Plant biotechnology}

\section{Introduction}

The photosynthesizing organisms, notably plants, are responsible for binding solar energy to organic matter and hence provide the source of food and bioenergy on earth. Owing to the growing human population and the globally increasing demand for energy and food, improved technologies for enhanced utilization of nutrients and renewable energy provided by plants are needed. Development of plant tissue culture techniques, discovery of DNA-modifying enzymes, and the technologies for genetically transforming cells provided grounds for development of plant biotechnology. Although gene technology represents only one of the areas of plant biotechnology and is not yet utilized in field crop or horticultural production in Finland, to public it is the best known field of biotechnology due to the debates about benefits and putative environmental and health risks associated with gene technology (Weaver and Morris 2005, Ramessar et al. 2007).

The Faculty of Agriculture and Forestry (AF) at the University of Helsinki (UH) is devoted to promote sustainable use of renewable natural resources, including cultivated plants and forest trees. Plant biotechnology became an integral part of teaching and research at AF-UH soon after the relevant, fundamental key discoveries in plant molecular biology had been made abroad in the early 1980 's. The role of biotechnology continues to increase at AF-UH in collaboration with other departments and the Institute of Biotechnology that have recently moved to the Viikki Campus where the agricultural departments of UH have been located since the 1960s. Today, Viikki constitutes one of the largest life science campuses in Europe. The scientists in Viikki have extensive international collaboration networks, which is necessary for cutting-edge science, but in interest of space it will not be possible to refer to all details here.

Looking to the past, the current strengths of the Viikki Campus in plant biotechnology developed in various projects at different institutes. While there is also no space to exclusively review the historical aspects, some of the main steps should be mentioned. Plant tissue culture methods paved the way to other techniques of plant biotechnology and were established for many species, including agricultural and horticultural crops and forest trees (Simola \& Sopanen 1971, Tapio 1972, Simola \& Honkanen 1983, Huhtinen et al. 1983, Simola 1985). They are an integral part of the breeding schemes utilizing somatic embryogenesis or hybridization and plant transformation procedures. Stable transformation of plant genomes using the natural mechanism encompassed by the Ti-plasmid of Agrobacterium tumefaciens, a plant-pathogenic bacterium, was achieved in several laboratories in the early 1980s (Bevan et al. 1983, Zambryski et al. 1983). Subsequently, the Finnish Innovation Fund SITRA funded a project to develop gene transfer methods and suitable expression vectors for plant transformation to acquire the technology for domestic use. The first $\mathrm{PhD}$ thesis in Finland utilizing gene transfer methods in plants came out from these activities (Teeri 1988). Gradually, more plant-related projects began to exploit gene technology and various other plant biotechnology methods such as somatic hybridization.

The longest traditions in Finland are in barley and potato biotechnology due to the outmost importance of these crops for the agriculture of this country. The first procedures for cell and tissue culture (Foroughi-Wehr et al. 1976, Sorvari 1986, Lührs and Lörz 1987) and regeneration of protoplasts (Yan et al. 1991) of barley were developed in the 1970s and 1980s. Barley, as also other monocotyledonous plant species, was initially found to be recalcitrant to Agrobacteriummediated transformation. Therefore, alternative transformation methods such as gene delivery by electrophoresis (Ahokas 1989), biolistic particle bombardment, electroporation and micro-injection were developed. Among the first reports on stable transformation of barley were those published by teams of researchers at the Institute of Biotechnology, UH, and the VTT Technological Research Centre Finland (VTT) who used particle bombardment as the method for transformation (Ritala et al. 1993, 1994). Later, successful methods for genetic transformation of barley were also reported with $A$. tumefaciens (Tingay et al. 1997). Developments in potato biotechnology are reviewed below. Forest 
Vol. 17 (2008): 307-324.

biotechnology experienced a break-through when transgenic birch trees were produced at the University of Joensuu (Keinonen-Mettälä et al. 1998). The work was continued in Viikki at AF-UH (Pappinen et al. 2002). The key methods developed on birch are now among the cornerstones of the forest biotechnology research in the Viikki Campus which, however, is not reviewed here.

Research and education on breeding, production and utilization of agricultural and horticultural plants and protection of crops against pests and diseases are the task of the relatively recently established Department of Applied Biology (DAB) at the AF-UH. The methods of plant biotechnology are widely used to study these topics and produce scientific data for development of relevant applications. The bio-safety and environmental impacts related to plant biotechnology applications have also been actively investigated at DAB. For example, DAB has coordinated a national research programme entitled Environmental, Societal and Health Effects of Genetically Modified Organisms (ESGEMO) funded by the Academy of Finland and relevant ministries to provide sound, science-based information for authorities working on legislation and regulatory issues.

The aim of this review is to highlight the current research in plant biotechnology carried out on agricultural and horticultural crops at DAB, and provide some visions for the future. The studies on potato biotechnology, flower development in gerbera, production of edible vaccines and heterologous proteins in plants, and the use of molecular markers will be highlighted as examples to illustrate how plant biotechnology could contribute to the efficient and sustainable use of plant resources.

\section{Potato biotechnology}

Cultivation of potato (Solanum tuberosum L.) is based on vegetative propagation of cultivars by planting tubers. Potato is also the first major crop species (ranking the fourth in production in the world, Vreugdenhil et al. 2007) for which vegeta- tive propagation of plants in vitro was established using meristem tip culture (Morel and Martin 1955). The driving force at that time was the need to obtain virus-free and phytoplasma-free plants from infected cultivars and hence increase the yields of the crop. Potato belongs to the family Solanaceae also including tobacco (Nicotiana tabacum L.) that was the main model species for development of tissue culture techniques (Murashige and Skoog 1962) and plant transformation (Zambryski et al. 1983). Potato was also found to be amenable to these methods. Anther-derived haploid production (Wenzel and Uhrig 1981), protoplast fusion (Skarzhinskaya et al. 1982), somatic hybridization (Sidorov et al. 1987), genetic transformation (An et al. 1986) and other in vitro techniques have been widely used on potato for breeding and research purposes (reviewed in Bradshaw and Mackay 1994, Vreugdenhil et al. 2007).

Boreal Plant Breeding Ltd utilizes the current methods of plant biotechnology in Finland. AF-UH has been involved in building up some of the technologies used. The techniques required for potato protoplast fusion and interspecific somatic hybridization were introduced to the former Department of Crop Husbandry (now part of DAB) at AF-UH in 1990. The studies were initially based on somatic hybrids developed at Rothamsted Experimental Station, UK, where some of the researchers had previously worked but where these activities were not continued (Pehu et al. 1990, Valkonen et al. 1991, 1994, Xu et al. 1993). There were also other departments with interest to enhance utilization of biotechnology and, hence, a joint biotechnology laboratory of AF-UH was established in the Cbuilding in Viikki by several research groups from different departments. Studies on potato biotechnology at $\mathrm{DAB}$ were continued in a joint project with the plant breeding unit of the MTT Agrifood Research Finland (MTT) and Boreal Plant Breeding Ltd. A few years later, UniCrop Ltd was founded by some of the researchers at AF-UH and the commercially oriented lines of plant biotechnology research moved to the company. The chain of events leading to establishment of plant biotechnology at AF-UH, including the challenges and difficulties in fitting academic studies and commercially oriented 


\section{Elomaa, P. et al. Plant biotechnology}

research into the same laboratory at a university department, have been reviewed in detail by Tuunainen (2005a, 2005b).

A novel biotechnology-based breeding scheme was developed by AF-UH, MTT and Boreal Plant Breeding Ltd to enhance potato breeding. Cultivated potato is tetraploid $(2 \mathrm{n}=4 \mathrm{x}=48)$ and cultivars are highly heterozygous. Reduction of ploidy to the dihaploid level $(2 n=2 x=24)$ is needed for detection of phenotypes that are masked in the tetraploid cultivars and also for crosses with many diploid $(2 \mathrm{n}=2 \mathrm{x}=24)$ wild potato species (Watanabe et al. 1995). Therefore, anther culture-based haploid production from commercial potato cultivars was studied and developed (Tiainen 1992, Rokka et al. 1996a). The dihaploid potato lines were electrofused to obtain putative new cultivars (Rokka et al. 1996b). Protoplasts of the dihaploid potato lines were also electrofused with protoplasts of the diploid, disease-resistant wild species $S$. brevidens and $S$. acaule to introduce novel genes to the breeding material (Rokka et al. 1994, 1998). Subsequently, the interspecific somatic hybrids were subjected to haploid-induction via anther culture in order to reduce their ploidy levels (Rokka et al. 1995, Gavrilenko et al. 2002). The new 'somatohaploid' plants were used for production of 'second-generation' somatic hybrids with dihaploid potato lines (Rokka et al. 2000, Gavrilenko et al. 2002). Hence, the cultivated potato gene pool and thereby fertility and chances to make sexual crosses with potato breeding lines were increased. Besides representing a novel potato breeding scheme based on biotechnology methods, the studies produced a lot of fundamental, new information about the somatic, cytogenetic and sexual compatibility of distantly related Solanum species and utility of the disease resistance traits expressed by them. It was also found that the somatic hybrids of potato and $S$. brevidens synthesize a novel glycoalkaloid that was not found in the parental genotypes (Laurila et al. 1996). This finding opened an important new line of research because glycoalkaloids are considered as potential biomolecules in pharmaceutical industry, which is a study area currently pursued at VTT.
The new possibilities which gene technology provides for improvement of important traits in crop plants were demonstrated in Finland already in the beginning of the 1990s. Institute of Biotechnology, UH, and the state-owned company Kemira used gene technology to construct novel forms of virus resistance in potato. The innovation was based on knowledge at the molecular level of a virus defence mechanism operating in mammalians. Potato plants were transformed with the 2'-5' oligoadenylate synthase gene that was isolated from rat. The gene plays a key role in the interferoninduced antiviral defense pathway in mammalians, including man. Results showed that transfer of the single gene from rat was sufficient for activation of resistance to Potato virus $X$ (PVX) in potato (Truve et al. 1993). The level of protection was at least as good as that obtained using the coat protein gene of PVX for potato transformation. This latter approach, coined as pathogen-derived resistance, had been published a few years earlier in the USA (Powel-Abel et al. 1986). Kemira also collaborated with Moscow State University to develop broadspectrum, pathogen-derived resistance to several viruses in potato using a modified viral movement protein gene as the transgene. The resistance was thought to be protein-mediated (Seppänen et al. 1997). At the same time at the former Department of Plant Production (now part of DAB) in AF-UH, potato cv. Pito was transformed with a genomic region of Potato virus $Y$ (PVY) that encodes the first viral protein $\mathrm{P} 1$. The transgenic plants were highly and specifically resistant to PVY (Pehu et al. 1995). Inserting the transgene in an antisense (non protein-encoding) orientation to the potato genome also provided resistance to PVY. Therefore, the resistance was RNA-mediated (Mäki-Valkama et al. 2000). All these innovations were patented. Currently, RNA-mediated inhibition of virus replication and plant gene expression (called RNA silencing or RNAi) are widely studied and utilized techniques. They induce or mimic the natural cellular mechanism that regulates gene expression at an RNA level and also protects cells against viruses (Haasnoot et al. 2007). In fact, it could be possible to control all viruses damaging potato by transforming potato cultivars to produce double- 
Vol. 17 (2008): 307-324.

stranded RNA (no protein) corresponding to a small region of the viral genome (Smith et al. 2000).

Gene technology enhances the use of natural disease resistance in crop plants in multiple ways. RNAi mentioned above is one of the examples. Another one is mapping of natural resistance genes and development of accurate molecular markers for their selection in potato breeding programs, which is widely used (Gebhardt and Valkonen 2001, Gebhardt et al. 2006). Genetic mapping can be continued to gene isolation and, eventually, the resistance gene can be transferred to susceptible cultivars by means of genetic engineering. The former Department of Plant Production (now part of DAB) and The Institute of Biotechnology at UH, and Cornell University in the USA identified the chromosomal locus of $R y_{a d g}$, the first gene for resistance to PVY mapped in the potato genome (Hämäläinen et al. 1997). The same region of potato chromosome XI was found to contain also a gene for resistance to Potato virus A (PVA) (Hämäläinen et al. 1998, 2000). A gene $\left(N x_{p h u}\right)$ for resistance to PVX was mapped in the cultivated potato species $S$. phureja (Tommiska et al. 1998). Reliable polymerase chain reaction (PCR) based markers were developed for $R y_{a d g}$ (Sorri et al., 1999, Kasai et al. 2000) and are now used by potato breeders (e.g., Gebhardt et al. 2006, Rizza et al. 2006). Another gene, $R y_{s t o}$, that also confers extreme resistance to all strains of PVY was studied in potato materials originating in the International Potato Center (CIP), Peru, and PCR-based markers were developed for use in breeding programmes (Valkonen et al. 2008). A resistance gene homologue from the chromosomal region containing $R y_{\text {adg }}$ (Vidal et al. 2002) and two new potato genes encoding proteins that interact with the HC-Pro protein of PVA (Guo et al. 2003) have been isolated and their putative use as novel virus resistance factors is being elucidated. Many additional, putative genes involved in inducible resistance to viruses and Rhizoctonia solani in potato have been detected at DAB using potato cDNA microarrays (Lehtonen et al. 2008 b, A. Vuorinen, et al., unpublished).

One of the early begun and still ongoing topics of plant research at UH with specific importance for Nordic countries has been investigation of cold and frost tolerance in plants (Kurkela et al. 1988), including potato. Genes from a wild, cold-tolerant potato species, S. commersonii, have been introgressed to the cultivated potato gene pool via somatic hybridization and studied at $\mathrm{DAB}$ for their role in frost tolerance (Seppänen et al. 1998, 2000). Studies with a potato population derived from a self-pollinated somatic hybrid revealed that antioxidative capacity plays an important role in frost tolerance. Various genes responding to low temperatures or associated with accumulation of active oxygen species at low temperature and intensive light were identified (Seppänen and Fagerstedt 2000, Seppänen and Coleman 2003). These studies were continued to increase understanding of the genetic and physiological basis of the nonacclimated freezing tolerance in potato. Sequences of the genes responsive to low temperature were found to be nearly identical in the freezing tolerant and freezing sensitive potatoes, whereas the constitution of the cis-acting factors in the promoter sequences varied. Possibilities to engineer freezing tolerance in potato by the means of gene technology are currently under study by over-expressing the low temperature regulated genes and testing activation of the promoters following various environmental stimuli in plants and tubers (M. Seppänen, G. Coleman and O. Junttila, unpublished).

Since 2000, a large program has been carried out jointly by MTT (Ruukki research station, Seed Potato Biotechnology group), DAB and private sector stakeholders to utilize biotechnological methods for diagnostics of pathogens and analysis of physiology of seed potatoes in order to enhance quality and increase the export of seed potatoes from Finland. The main seed potato production area is located in northern Ostrobothnia with good soils for potato production in an area free of quarantine pathogens and with a low pressure from potato pests and diseases. This High Grade Seed Potato Production Zone (approved by European Union) used to have a security zone of thousands of hectares in which potatoes from outside were not allowed to be grown. The first yields of the highest pathogen-indexed potato seed classes were harvested in the protected zone in 1976 (Pietarinen and Seppänen 1981). Furthermore, DAB has 
Elomaa, P. et al. Plant biotechnology

recently applied cryotherapy as a novel means for eradication of viruses and phytoplasma from vegetatively propagated plants, which results in virusfree plants with a much higher frequency than the previously used methods (Wang et al. 2008, Wang and Valkonen 2008). At the same time, Laukaa Research and Elite Plant Unit of MTT has developed cryopreservation techniques for perennial horticultural plants (Wang et al. 2005) and in collaboration with $\mathrm{DAB}$ introduced the cryotherapy technique to healthy plant production. Consequently, Finland has become a forerunner in the use of this approach. These developments have their backgound in the 1970 s when in vitro techniques were introduced to production of virus-free clones of potato varieties (Tapio 1972), currants, gooseberry, raspberry and strawberry (Bremer and Ylimäki 1978, Uosukainen and Kurppa 1988). These activities were linked to AF-UH in several ways. Many key persons worked as docents or professors in plant pathology at AF$\mathrm{UH}$ or got their education at AF-UH.

\section{Biotechnology in horticultural species}

Research for developing biotechnological applications and products in floriculture in Finland was initiated as a joint undertaking of the private and public sectors (Kemira and The Institute of Biotechnology, UH, respectively) at the end of the 1980s (Törmälä et al. 1992, Elomaa et al. 1993). Besides many ornamental species, the efforts were strongly focused on gerbera (Gerbera hybrida), one of the most popular and economically significant cut flowers in Finland and worldwide. The value of international trade of gerberas channelled via the Dutch market alone exceeds 100 million euro annually (Teeri et al. 2006a). Efficient tissue culture, micropropagation and gene transfer methods were developed for this species (Törmälä et al. 1992). Consequently, modification of flowers colours in gerbera became one of the first examples of genetically modified traits in ornamentals (Elomaa et al. 1993). Later on, the possibility of producing genetically modified gerbera plants has greatly facilitated basic scientific research and made gerbera a well-recognized model species within flower developmental biology. This topic is currently emphasized at DAB (Teeri et al. 2006a, 2006b).

The first genes isolated from gerbera belonged to the anthocyanin pathway (Helariutta et al. 1993, 1995a). They could be engineered to modify flower colour (Elomaa et al. 1993). They also served as marker genes in studies of inflorescence development since pigmentation patterns in various gerbera varieties are strictly correlated with the anatomy of the complex inflorescence (Helariutta et al. 1995b). More recent studies have identified a number of regulatory genes that are required for organ and tissue specific activation of biosynthetic genes and anthocyanin pigmentation (Elomaa et al. 1998, 2003). These studies have provided intrinsic scientific information about transcriptional regulation of gene expression in plants.

Tissues of gerbera plants are very rich in secondary compounds that are attractive targets for molecular breeding (Teeri et al. 2006a). The studies on flavonoid pathway genes led to the discovery of a novel gene function responsible for synthesis of secondary compounds involved in pathogen and insect resistance in gerbera (Helariutta et al. 1995a, 1996, Eckermann et al. 1998). Recent studies at DAB indicate that the presence of these compounds correlates with resistance to Botrytis cinerea in different varieties of gerbera (S. Taalas and T. Teeri, unpublished). These studies serve as a good example of how results from basic research may quickly find their ways to applications.

The inflorescence of gerbera consists of morphologically different types of flowers with highly specialized floral organs. The complex structure distinguishes it from traditional model species used for studies on flower development. To this end, research has focused on transcription factor genes that contain a conserved 'MADS box' domain and encode key regulators of flower organ identity. Many novel functions for these regulators have been detected using transgenic plants that show distinct phenotypes. The results emphasize the importance of using gerbera for comparative 
Vol. 17 (2008): 307-324.

studies with other model species such as Arabidopsis thaliana (Yu et al. 1999, Kotilainen et al. 2000, Uimari et al. 2004, Teeri et al. 2006c). Recent studies have employed expressed sequence tag (EST) sequencing and cDNA microarrays for identification of new gene family members related to both secondary metabolism and flower development (Laitinen et al. 2005). Potentially useful genes for modification of fibre qualities for chemical industry have also been detected (Toikkanen et al. 2007). Large-scale gene expression profiling has been used to study regulation of flower type identity (Laitinen et al. 2006) and transcriptional changes during petal organogenesis (Laitinen et al. 2007). Comparison of the developing ray and disc flower primordia uncovered the expression of many MADS box genes that respond to the radially patterned zones of the capitulum. This finding implies that flower type-specific MADS box protein complexes are needed to regulate organ identity and differentiation of individual flower types (Laitinen et al. 2006). In addition to the MADS box regulators, the current work at DAB concentrates on 'TCP domain' transcription factors that are candidate regulators specifying flower type identity (Cubas 2004). Studies on flower development in gerbera, including regulation of organ growth (Kotilainen et al. 1999), have contributed to the basic understanding as to how gene functions and morphological diversification of flowering plants evolve. The rapid development of tools applicable to genomics research will evidently open up new possibilities to develop molecular markers for the key traits in gerbera and enhance reeding programs.

Strawberry (Fragaria $\times$ ananassa) represents another important horticultural species studied at DAB. It is the most important fruit crop cultivated in Finland. Furthermore, strawberry and the diploid, related wild species Fragaria vesca are emerging new model species the family Rosaceae that contains a plenty of important horticultural plants. The current research at DAB in collaboration with MTT and University of Florida concentrates on physiology and genetic regulation of flowering and also yield formation (Hytönen et al. 2004, Sønsteby and Hytönen 2005). The studies on the role of gibberellic acid (GA) in axillary bud differentiation in strawberry have already led to practical applications in the field. Strawberry yields can be increased by exogenous application of a GA biosynthesis inhibitor, that enhances crown branching on the cost of runner production (K. Mouhu and T. Hytönen, unpublished). The genetic pathways controlling flowering in the short day adapted plants, such as strawberry, are still poorly understood but studies to this direction have been initiated. Sequencing of cDNA subtraction libraries have been used to identify genes that are induced during the floral transition of Fragaria vesca. They will be critically tested for functions in transgenic plants.

\section{Production of heterologous proteins in plants}

Proteins intended for industrial and medical uses are needed in increasing amounts. Microbial systems are commonly used for production of heterologous proteins but they are not always optimal, e.g., because certain post-translational modifications that occur in eukaryotic cells are lacking in microbes. Plants offer a safe, easily scaleable and cost-effective eukaryotic expression system for production of heterologous proteins. "Biopharming" of high-value proteins, such as the plant-made pharmaceuticals (PMP, including subunit vaccines and antibodies) for human and veterinary use, are targets of intensive academic research as well as commercial research and development (Fischer et al. 2004, Stoger et al. 2005, Floss et al. 2007). In USA and Canada, ca. 20 PMPs for human use are in clinical trials (most of them in Phase II) and some of them should reach the market stage in the near future (Spök 2007). The first PMP that has achieved a regulatory approval was a veterinary vaccine against Newcastle disease in poultry (February 26, 2006, in the USA) (Vermij and Waltz 2006). The system is based on protein expression in plant cells rather than whole plants and production is done in a secure, bio-contained environment. 
Elomaa, P. et al. Plant biotechnology

DAB has recently led or been involved in three projects devoted to development of plant-based heterologous protein production systems. Two projects will be reviewed below. The third project is done in collaboration between VTT, AF-UH and Fibrogen Europe/Fibrogen Inc. and aims to produce recombinant gelatine in barley seeds. The results from transgenic barley have clearly shown that the concept of using barley grains for production of industrially important proteins is applicable (reviewed in Mäkinen and Nuutila 2004).

\section{Production of edible vaccines in trans- genic plants}

There is significant interest on developing safe and inexpensive PMPs for use as veterinary vaccines. The approach offers advantages in safety and cost of delivery and manufacture. PMPs can be harvested, stored and delivered to target animals as they are, i.e. by directly mixing them with the animal feed. For example, edible leaves or grains are therefore good candidates for the vehicle of veterinary vaccines. Furthermore, the regulatory processes are greatly simplified for animal vaccines, as compared to medical use. Orally administrated plant-made vaccines may also offer a future solution to the struggle against many diseases among wild animals, such as rabies, Newcastle disease, foot-and-mouth disease and Avian flu (Streatfield 2005)

DAB has recently led the development of an oral vaccine to porcine postweaning diarrhea (PWD), which was carried out in collaboration with Department of Biosciences (UH), VTT, MTT, University of Ghent and University of Brussels. PWD is a major problem in pig farming in Finland and worldwide, resulting in significant economic losses, and no vaccine is available. PWD is caused by the F4-positive enterotoxigenic Escherichia coli (ETEC) strains. F4 fimbriae are the major colonization factors of the bacteria associated with PWD. The fimbriae are assembled as long polymers of the major subunit FaeG which is also responsible for the adhesive properties of the fimbriae. Being highly stable and mucosally immunogenic F4/
FaeG offer a unique model system to study oral vaccination against PWD (Van den Broeck et al. 1999, Verdonck et al. 2004).

The FaeG gene isolated from an ETEC strain was initially used to transform tobacco plants to optimize the production system. As much as 70 mg FaeG per kilogram fresh weight (1\% of the total soluble proteins, TSP) was produced in the leaves of the transgenic tobacco plants when the recombinant protein was targeted to chloroplasts. The chloroplast-derived FaeG tolerated low $\mathrm{pH}$ and was resistant to proteolysis under the conditions simulating gastrointestinal tract of weaned piglets (Snoeck et al. 2004, Joensuu et al. 2004). FaeG could also bind the intestinal F4 receptor (F4R) and inhibit the F4-positive ETEC binding to F4R in a dose-dependent manner (Joensuu et al. 2004).

Subsequently, immunogenicity of plant-produced FaeG protein was studied by transforming edible alfalfa (Medicago sativa L.) and barley plants with FaeG. The chloroplast-targeted FaeG accumulated to $1 \%$ of TSP in alfalfa leaves (100 $\mathrm{mg} / \mathrm{kg}$ dry weight) (Joensuu et al. 2006b). FaeG accumulated also to $1 \%$ of TSP $(670 \mathrm{mg} / \mathrm{kg}$ dry weight) in barley seeds when the FaeG-encoding gene was expressed under an endosperm-specific promoter and subcellularly targeted to the endoplasmic reticulum (Joensuu et al. 2006a). Desiccated alfalfa leaves and barley grains maintained the FaeG protein in a stable form for years. These results were promising because sufficient concentration and stability over a long-term storage are requirements for edible vaccines.

The most important finding of the study was that the plant-expressed FaeG was immunogenic to animals. When the TSP of barley seeds was injected subcutaneously to mice, F4-specific antibody response was observed and the sera inhibited adhesion of the F4-positive ETEC to F4R on piglet enterocytes in vitro (Joensuu et al. 2006a). The transgenic alfalfa plants were orally administered to weaned piglets, which resulted in F4-specific systemic and mucosal immune responses (Joensuu 2006, Joensuu et al. 2006b). In the following ETEC challenge the duration and number of $E$. coli excretion were significantly reduced to a level observed 
Vol. 17 (2008): 307-324.

with positive control group immunized with purified F4 fimbriae.

In conclusion, these results suggest that transgenic plants producing the FaeG subunit protein could be used for production and delivery of mucosal vaccines against $\mathrm{F}^{+}$ETEC infections. Furthermore, structural modification of FaeG may provide additional possibilities. Because of their incomplete folding, fimbrial subunits are unstable and susceptible to aggregation and/or proteolytical degradation in the absence of their chaperone. However, in chloroplasts FaeG protein was expressed in a stable and soluble form. FaeG was purified from chloroplasts, studied using x-ray crystallography and found to assemble to unusual strand-swapped dimers. While providing the first crystal structure of a plant-made vaccine (Van Molle et al. 2007) the results also allowed making a high-resolution model of structure of the F4 fimbria and paved a way to design of more immunogenic and stable FaeG vaccines in the future.

\section{Expression of heterologous proteins from a vector virus}

Viruses can be used as gene vectors to express heterologous proteins in the infected plants (reviewed by Pogue et al. 2002, Gleba et al. 2004). RNA viruses are particularly suitable for this purpose, also from biosafety point-of-view, because the viral RNA genome does not integrate into genome of the plant but replicates in the cytoplasm. As compared to transgenic plants, vector viruses offer a more speedy and flexible system for use, however, including the same benefits as with transgenic plants. Most viruses complete the systemic infection of plants within two weeks and most tissues of the plant would accumulate the heterologous protein by then. The vector-virus based production system can be transferred to any new host species or genotype of the virus simply by inoculation; no plant transformation, regeneration and selection are needed.

The genus Potyvirus contains the largest number of virus species $(>150)$ infecting a vast number of plant species (Rajamäki et al. 2004), which makes them attractive as vector viruses. Furthermore, they express their genome as a large polyprotein that is subsequently processed to up to ten mature proteins by the viral proteinases. Hence, a foreign gene inserted into the viral genome will be translated as part of the polyprotein and the heterologous protein produced in equimolar amounts with viral proteins. Proteolytic processing of the heterologous protein requires that the appropriate proteolytic cleavage sites are engineered to flank the protein. Following cleavage, a few amino acid residues from the viral polyprotein will remain at the termini of the heterologous protein. However, in most cases this does not seem to intervene with the activity or purpose of use of the heterologous protein.

PVA belongs to potyviruses and has been a model for molecular studies of potyviruses at UH. The studies were initiated at the Institute of Biotechnology and are continued at AF-UH. A full-length, infectious cDNA is now available from two PVA strains with a slightly different host range (Puurand et al. 1996, Paalme et al. 2004). The potyviral genome contains two positions (P1/ $\mathrm{HC}$-Pro and $\mathrm{NIb} / \mathrm{CP}$ ) suitable for inserting foreign sequences without greatly affecting viral infectivity (Dolja et al. 1992, Varrelman and Maiss 2000) and can be used also in PVA (Ivanov et al. 2003, Kelloniemi et al. 2006). A third, novel cloning site inside the P1 encoding region of PVA was detected by a transposone-based insertion mutagenesis approach (Kekarainen et al. 2002).

Catechol-O-methyltransferase (S-COMT) is a human protein associated with the metabolism of chatechol estrogens and degradation of the catecholamine neurotransmitters dopamine and epinephrine. Recombinant S-COMT is needed in pharmaceutical industry for development S-COMT inhibitors for the treatment of Parkinson's disease (Lundström et al. 1991). S-COMT was expressed in active form from the $\mathrm{NIb} / \mathrm{CP}$ site of the PVA vector in Nicotiana plants (Kelloniemi et al. 2006). Yields of S-COMT reached $0.7-0.8 \%$ of TSP, which is slightly less than $2 \%$ observed with the viral coat protein, possibly due to lower stability of $\mathrm{S}-\mathrm{COMT}$. The cloning site in the P1 region was, in turn, used to express the green fluorescent protein (GFP) of jellyfish, Aequorea victoria (Rajamaki et 
Elomaa, P. et al. Plant biotechnology

al. 2005). In both cases, virus levels were slightly reduced but, on the other hand, also symptoms were alleviated which is beneficial for the use of the production system. These results showed that human and animal proteins can be produced from the PVA vector in plants.

Recently, the three cloning sites were combined in a single, chimeric PVA genome. The vector virus is infectious and produces the three heterologous proteins (Kelloniemi et al. 2008). This is the first viral vector from which three heterologous proteins can be produced simultaneously, which provides unique possibilities not only for PMP production but also scientific research. These examples demonstrate that while being harmful pathogens, the viruses also possess potential for development to biotechnological tools (Valkonen 2007).

\section{Molecular markers and their multiple uses}

DNA-based molecular markers differentiate individuals based on single-base substitutions or larger genetic differences at the genome level. Many examples of the use of molecular markers for gene mapping and marker-assisted selection (MAS) in plant breeding have already been mentioned above. One additional example at DAB is the transfer of herbicide (imidazolinone, IMI) tolerance from Brassica napus L. to B. rapa L. by conventional means using hybrid breeding (Haukkapää et al. 2005, Niemelä et al. 2006). The tolerance of IMI is based on a chemically induced mutation of the acetolactate synthase (ALS) gene in B. napus (Swanson et al. 1989). MAS is used for selection of the mutated $A L S$ gene and the fertility-restoring $(R f)$ gene that is needed to overcome cytoplasmic male sterility of the hybrids. Furthermore, plants homozygous and heterozygous for the Rf locus are distinguished using allelic specific probes and quantitative polymerase chain reaction (A.-L. Haukkapää, T. Niemelä, U. Tulisalo and M. Seppänen, unpublished).
DNA markers are mostly phenotypically and selectively neutral and thus suitable for studies on population genetics and gene flow. Molecular and population genetics studies are carried out at DAB on several plant groups, including also algae and non-vascular plants such as mosses which are photosynthesizing organisms important to the ecosystems affected by or interacting with the agricultural and forest environments. For example, mosses are used as model organisms to study gene flow, population genetic structures and adaptation (Korpelainen et al. 2005, Pohjamo et al. 2006) and also evolution of pathogen resistance in plants (Akita and Valkonen 2002, Andersson et al. 2005, Lehtonen et al. 2006). Dispersal, colonization and gene flow are important to species in order to avoid population decline and extinction. They are particularly important to endangered species that may suffer from fragmentation of habitats and the genetic, demographic and environmental consequences of the decrease in population size. Many types of molecular markers are used to study gene flow, plant genetic resources and the early stages of gender determination of dioecious plant species (Korpelainen 2002, Korpelainen et al. 2007, Korpelainen and Kostamo 2007). Novel transposonbased markers for plants have been developed in the MTT research laboratory located in the Viikki campus (Kalendar et al. 1999).

Molecular markers are also widely used for the study of plant pathogens, plant-microbe interactions, pathogen populations and microbial ecology. These are important study areas related to plant biotechnology carried out at DAB (Lehtonen et al. 2004, 2008a, Mattinen et al. 2004, Aittamaa et al. 2008, Hiltunen et al. 2008), other departments of AF-UH and the Viikki Campus (e.g., Pitkäjärvi et al. 2003, Jussila et al. 2006, Sjöblom et al. 2006). At DAB, these studies are carried out on many crop plant species and their pathogens and also on the model species Arabidopsis thaliana (Karim et al. 2007) and the moss, Physcomitrella patens, to understand evolutionary early-developed mechanisms of pathogen defence in plants (Akita and Valkonen 2002, Andersson et al. 2005, Lehtonen et al. 2006). However, these study areas are not emphasized in this review. 
Vol. 17 (2008): 307-324.

Transfer of knowledge in biotechnology and biosafety issues to agricultural institutes in the developing countries (e.g., the BIO-EARN programme with East African countries and the NIFAPRO project with Nicaragua) is considered as an important task at DAB and at AF-UH. The use and development of various kinds of molecular markers are typically included in these projects as the techniques are relatively robust and can be acquired in newly established laboratories which do not yet have a large range of equipment.

Considering also the study fields of agroecology and agricultural entomology affiliated at DAB, the department has a broad and deep expertise not only for developing plant-based biotechnological applications for agricultural and horticultural use but also for studying and monitoring the environment with the help of molecular tools (e.g., Seppänen et al. 2007). This is important for risk assessment and development of practises which reduce any inadvertent negative consequences that plant production may have to the environment.

\section{Structures facilitating progress in plant biotechnology research}

Plant biotechnology is one of the strengths at AFUH and the Viikki campus, both from the national and international perspective. This is largely the result of close and fruitful collaboration of the research groups affiliated by different departments and faculties and the national and international collaboration. These developments need to be supported and continued.

At AF-UH, the merger of several small departments to form the current DAB in 2002 brought all plant science-oriented disciplines administratively together. Consequently, crop science, plant breeding, plant pathology and horticulture currently share the same laboratory space and equipment at DAB. The close interaction has resulted in new joint research interests, including devel- opment of plant viruses as gene silencing tools for studies in functional genomics.

Joint research activities across faculty borders have been an important foundation for the very well developed collaboration in teaching of courses in plant science. Furthermore, a national graduate school in plant sciences is coordinated from the Viikki campus. A Centre of Excellence (CoE) has been formed in Viikki and funding awarded by the Academy of Finland for periods of 2000-2005 (CoE in Plant Molecular Biology and Forest Biotechnology) and 2006-2011 (CoE in Plant Signal Research). One of its most significant achievements has been the development of plant genome resources for a wide use in Finland, e.g., the large EST collection of spruce (Koutaniemi et al. 2007) and birch, and the microarray of birch.

The plans include that the strong plant science community at Viikki campus will be reinforced by gathering all scientists who are involved in experimental plant research to a joint "Viikki Plant Science Centre" (VPSC) which could also affiliate research groups from other organizations, as appropriate. This is feasible due to the already existing collaboration in research and teaching which can be further synergized. VPSC will be particularly important for maintenance of the up-to-date research facilities and technologies specifically required for plant biotechnology. Some of the core facilities and technology platforms needed in plant biotechnology research are maintained by the Institute of Biotechnology but used by all research groups in the Viikki Campus. These platforms included electron microscopy, DNA sequencing, and microarray and protein analysis that are essential for plant genomics research. The research groups using the facilities have also contributed to their development in terms of funding and expertise. Indeed, concentrating the more expensive and demanding technologies to the commonly shared platforms is crucial for maintaining the cutting-edge, rapidly developing technologies and know-how of them at the reach of the plant research community in Viikki. The latest addition to the arsenal of high throughput sequencing is the " 454 " massive parallel sequencing platform, with which sequencing of the EST libraries of gerbera and strawberry and 
Elomaa, P. et al. Plant biotechnology

the full genome of the bacterial potato pathogen, Pectobacterium carotovorum, will be achieved by the end of 2008.

In conclusion, plant biotechnology research at AF-UH and the Viikki campus contributes to solution of the important domestic pitfalls in plant production and creates new technologies and applications for the sustainable use of plant resources. Renewable biomass resources are needed to replace the fossil fuels. Value-added crops capable to produce new types of biopolymers and structural components should be developed. Crop plants need to be adapted to the climatic change and hunger alleviated via enhanced crop production in the developing countries. The plant research capacity will be needed and must be further developed for solving the challenges of the challenges of food and energy production that are getting more severe.

\section{References}

Ahokas, H. 1989. Transfection of germinating barley seed electrophoretically with exogenous DNA. Theoretical and Applied Genetics 77: : 469-472.

Aittamaa, M., Somervuo, P., Pirhonen, M., Mattinen, L., Nissinen, R., Auvinen, P. \& Valkonen, J.P.T. 2008. Distinguishing bacterial pathogens of potato using a genome-wide microarray approach. Molecular Plant Pathology 9 , in press.

Akita, M. \& Valkonen, J.P.T. 2002. A novel gene family in moss (Physcomitrella patens) shows sequence homology and a phylogenetic relationship with the TIR-NBS class of plant disease resistance genes. Journal of Molecular Evolution 55: 595-605.

An, G., Watson, B.D. \& Chiang, C.C. 1986. Transformation of tobacco, tomato, potato, and Arabidopsis thaliana using a binary Ti vector system. Plant Physiology 81: 301-305.

Andersson, R.A., Akita, M., Pirhonen, M., Gammelgård, E. \& Valkonen, J.P.T. 2005. Moss-Erwinia pathosystem reveals possible similarities in pathogenesis and pathogen defence in vascular and non-vascular plants. Journal of General Plant Pathology 71: 23-28.

Bevan, M.W., Flavell, R.B. \& Chilton, M.D. 1983. A chimaeric antibiotic resistance gene as a selectable marker for plant cell transformation. Nature 304: 184-187.

Bradwshaw, J.E. \& Mackay, G.R. 1994 (eds). Potato Genetics. CAB International, Wallingford, UK, $552 \mathrm{p}$.

Bremer, K. \& Ylimäki, A. 1978. A certificate system to produce and distribute virus tested propagation material from berry plants in Finland. Annales Agriculturae Fenniae 17: 42-44.
Cubas, P. 2004. Floral zygomorphy, the recurring evolution of a successful trait. BioEssays 26: 1175-1184.

Dolja, V.V., McBride, H.J. \& Carrington J.C., 1992. Tagging of plant potyvirus replication and movement by insertion of beta-glucuronidase into the viral polyprotein, Proceedings of the National Academy of Science of the USA 89: 10208-10212.

Eckermann, S., Schröder, G., Schmidt, J., Strack, D., Edrada, R.A., Helariutta, Y., Elomaa, P., Kotilainen, M., Kilpeläinen, I., Proksch, P., Teeri, T.H. \& Schröder, J. 1998. New pathway to polyketides in plants. Nature 396: 387-390.

Elomaa, P., Honkanen, J, Puska, R, Seppänen, P., Helariutta, Y, Mehto, M, Kotilainen, M., Nevalainen, L. \& Teeri, T.H. 1993. Agrobacterium-mediated transfer of antisense chalcone synthase cDNA to Gerbera hybrida inhibits flower pigmentation. Bio/Technology 11: 508-511.

Elomaa, P., Mehto, M, Kotilainen, M., Helariutta, Y., Nevalainen, L. \& Teeri, T.H. 1998. A bHLH transcription factor mediates organ, region and flower type specific signals on dihydroflavonol-4-reductase (dfr) gene expression in the inflorescence of Gerbera hybrida (Asteraceae). Plant Journal 16: 93-99.

Elomaa, P., Uimari, A., Mehto, M., Albert, V.A., Laitinen, R.A.E. \& Teeri, T.H. 2003. Activation of anthocyanin biosynthesis in Gerbera hybrida (Asteraceae) suggests conserved protein-protein and protein-promoter interactions between the anciently diverged monocots and eudicots. Plant Physiology 133: 1831-1842.

Fischer, R., Stoger, E., Schillberg, S., Christou, P. \& Twyman, R.M. 2004. Plant-based production of biopharmaceuticals. Current Opinion Plant Biology 7: 152-158.

Floss, D.M., Falkenburg, D. \& Conrad, U. 2007. Production of vaccines and therapeutic antibodies for veterinary applications in transgenic plants: an overview. Transgenic Research 16: 315-332.

Foroughi-Wehr, B., Mix, G., Gaul, H. \& Wilson, H.M. 1976. Plant production from cultured anthers of Hordeum vulgare L. Zeithschrift für Pflanzenzucht 77: 198-204.

Gavrilenko, T., Larkka, J., Pehu, E. \& Rokka, V.M. 2002. Identification of mitotic chromosomes of tuberous and non-tuberous Solanum species (Solanum tuberosum and Solanum brevidens) by GISH in their interspecific hybrids. Genome 45: 442-449.

Gebhardt, C., Bellin, D., Henselewski, H., Lehmann, W., Schwarzfischer, J. \& Valkonen, J.P.T. 2006. Marker-assisted combination of major genes for pathogen resistance in potato. Theoretical and Applied Genetics 112: 1458-1464.

Gebhardt, C. \& Valkonen, J.P.T. 2001. Organization of genes controlling disease resistance in the potato genome. Annual Review of Phytopathology 39: 79-102.

Gleba, Y., Marillonnet, S. \& Klimyuk, V. 2004. Engineering viral expression vectors for plants: the 'full virus' and the 'deconstructed virus' strategies. Current Opinion of Plant Biology 7: 182-188.

Guo, D., Spetz, C., Saarma, M. \& Valkonen, J.P.T. 2003. Two potato proteins, including a novel RING-finger protein, interact with the potyviral multifunctional protein HC-Pro. Molecular Plant-Microbe Interactions 16 : 405-410.

Haasnoot, J., Westerhout, E.M., \& Berkhout, B. 2007. RNA 
Vol. 17 (2008): 307-324.

interference against viruses: strike and counterstrike. Nature Biotechnology 12: 1435-1443.

Hämäläinen, J.H., Kekarainen, T., Gebhardt, C., Watanabe, K.N. \& Valkonen, J.P.T. 2000. Recessive and dominant resistance interfere with the vascular transport of Potato virus $A$ in diploid potatoes. Molecular Plant-Microbe Interactions 13: 402-412.

Hämäläinen, J.H., Sorri, V.A., Watanabe, K.N., Gebhardt, C. \& Valkonen, J.P.T. 1998. Molecular examination of a chromosome region that controls resistance to potato $\mathrm{Y}$ and A potyviruses in potato. Theoretical and Applied Genetics 96: 1036-1043.

Hämäläinen, J.H., Watanabe, K.N., Valkonen, J.P.T., Arihara, A., Plaisted, R.L., Pehu, E., Miller, L. \& Slack, S.A. 1997. Mapping and marker-assisted selection for a gene for extreme resistance to potato virus $\mathrm{Y}$. Theoretical and Applied Genetics 94: 192-197.

Haukkapää, A-L, Junnila, S., Eriksson, C., Tulisalo, U. \& Seppänen, M. 2005. Efficacy of imazemox in imidazolinone-resistant spring oilseed rape in Finland. Agricultural and Food Science 14: 377-388.

Helariutta, Y., Elomaa, P., Kotilainen, M., Griesbach, R.J., Schröder, J. \& Teeri, T.H. 1995a. Chalcone synthase like genes active during corolla development are differentially expressed and encode enzymes with different catalytic properties in Gerbera hybrida. Plant Molecular Biology 28: 47-60.

Helariutta, Y., Elomaa, P., Kotilainen, M., Seppänen, P. \& Teeri, T.H. 1993. Cloning of cDNA coding for dihydroflavonol-4-reductase (DFR) and characterization of $d f r$ expression in the corollas of Gerbera hybrida (Compositae). Plant Molecular Biology 22: 183-193.

Helariutta, Y., Kotilainen, M., Elomaa, P. \& Teeri, T.H. 1995b. Gerbera hybrida (Asteraceae) imposes regulation at several anatomical levels during inflorescence development on the gene for dihydroflavonol-4-reductase. Plant Molecular Biology 28: 935-941.

Helariutta, Y., Kotilainen, M., Elomaa, P, Kalkkinen, N., Bremer, K., Teeri, T.H., \& Albert, V.A. 1996. Duplication and functional divergence in the chalcone synthase gene family of Asteraceae: evolution with substrate change and catalytic simplification. Proceedings of the National Academy of Science USA 93: 9033-9038.

Hiltunen, L.H., Ojanperä, T., Kortemaa, H., Richter, E., Lehtonen, M.J. \& Valkonen, J.P.T. 2008. Interactions and biocontrol of pathogenic Streptomyces strains cooccurring in potato scab lesions. Journal of Applied Microbiology, in press.

Huhtinen, O., Honkanen, J \& Simola, L.K. 1983. Ornithinesupported and putrescine-supported divisions and cell colony formation in leaf protoplasts of alders (Alnus glutinosa and A. incana). Plant Science Letters 28: 3-9.

Hytönen, T., Palonen, P., Mouhu, K. \& Junttila, O. 2004. Crown branching and cropping potential in strawberry (Fragaria $x$ ananassa Duch.) can be enhanced by daylength treatments. Journal of Horticultural Science \& Biotechnology 79: 466-471.

Ivanov, K., Puustinen, P., Gabrenaite, R., Vihinen, H., Rönnstrand, L., Valmu, L., Kalkkinen, N. \& Mäkinen, K. 2003. Phosphorylation of the potyvirus capsid protein by plant protein kinase CK2 and its relevance for virus infection" Plant Cell 15, 2124-2139.

Joensuu, J.J. 2006. Production of F4 fimbrial adhesin in plants: a model for oral porcine vaccine against enterotoxigenic Escherichia coli. Thesis/Dissertation. University of Helsinki, Finland

Joensuu, J.J, Kotiaho, M., Riipi, T., Snoeck, V., Palva, E.T., Teeri, T.H., Lang, H., Cox, E., Goddeeri,s B.M. \& Niklander-Teeri, V. 2004. Fimbrial subunit protein FaeG expressed in transgenic tobacco inhibits the binding of F4ac enterotoxigenic Escherichia coli to porcine enterocytes. Transgenic Research 13: 295-298.

Joensuu, J.J., Kotiaho, M., Teeri, T.H., Valmu, L., Nuutila, A.M., Oksman-Caldentey, K.M. \& Niklander-Teeri, V. 2006a. Glycosylated F4 (K88) fimbrial adhesin FaeG expressed in barley endosperm induces ETEC-neutralizing antibodies in mice. Transgenic Research 15: 359-373.

Joensuu, J.J., Niklander-Teeri, V. \& Brandle, J.E. 2008. Transgenic plants for animal health: plant-made vaccine antigens for animal infectious disease control. Phytochemistry Reviews 3: 553-577.

Joensuu, J.J., Verdonck, F., Ehrstrom, A., Peltola, M., Siljander-Rasi, H., Nuutila, A.M., Oksman-Caldentey, K.M., Teeri, T.H., Cox, E., Goddeeris, B.M. \& Niklander-Teeri, V. 2006b. F4 (K88) fimbrial adhesin FaeG expressed in alfalfa reduces F4+ enterotoxigenic Escherichia coli excretion in weaned piglets. Vaccine 24: 2387-2394.

Jussila, M.M., Jürgens, G., Lindström, K. \& Suominen, L. 2006. Genetic diversity of culturable bacteria in oil-contaminated rhizosphere of Galega orientalis. Environmental pollution 139: 244-257.

Kalendar, R., Grob, T., Regina, M., Suoniemi, A. \& Schulman, A. 1999. IRAP and REMAP: two new retrotransposon-based DNA fingerprinting techniques Theoretical and Applied Genetics 98: 704-711.

Karim, S., Holmström, K.O., Mandal, A., Dahl, P., Hohmann, S., Brader, G., Palva, E.T. \& Pirhonen, M. 2007. AtPTR3, a wound-induced peptide transporter needed for defence against virulent bacterial pathogens in Arabidopsis. Planta 225: 1431-1445.

Kasai, K., Morikawa, Y., Sorri, V.A., Valkonen, J.P.T., Gebhardt, C. \& Watanabe, K.N. 2000. Development of SCAR markers to the PVY resistance gene $R y_{\text {adg }}$ based on a common feature of plant disease resistance genes. Genome 43: 1-8.

Keinonen-Mettälä, K., Pappinen, A., \& von Weissenberg, K. 1998. Comparisons of the efficiency of some promoters in silver birch (Betula pendula). Plant Cell Reports 17: 356-361.

Kekarainen, T., H. Savilahti, \& J.P.T. Valkonen. 2002. Functional genomics on potato virus $A$ : virus genome-wide map of sites essential for virus propagation. Genome Research 12: 584-94.

Kelloniemi, J., Mäkinen, K., \& Valkonen, J.P.T. 2006. SCOMT and GFP, unlike sorcin, are successfully expressed from a potyvirus-based gene vector in plants. Biochimie 88: 505-513.

Kelloniemi, J., Mäkinen, K. \& Valkonen, J.P.T. 2008. Three heterologous proteins simulatenously expressed from a chimeric potyvirus: infectivity, stability and the correlation of genome and virion lengths. Virus Research 135: 282-291.

Korpelainen, H. 2002. A genetic method to resolve gender complements investigations on sex ratios in Rumex acetosa. Molecular Ecology 11: 2151-2156.

Korpelainen, H. \& Kostamo, K. 2007. Excessive variation 
Elomaa, P. et al. Plant biotechnology

in Y chromosomal DNA in Rumex acetosa (Polygonaceae). Plant Biology 9: 383-389.

Korpelainen, H., Kostamo, K. \& Virtanen, V. 2007. Microsatellite marker identification using genome screening and restriction-ligation. BioTechniques 42: 479-486.

Korpelainen, H., Pohjamo, M. \& Laaka-Lindberg, S. 2005. How efficiently does bryophyte dispersal lead to gene flow? Journal of the Hattori Botanical Laboratory 97: 195-205.

Kotilainen, M., Elomaa, P., Uimari, A., Albert, V.A., Yu, D. \& Teeri, T.H. 2000. GRCD1, an AGL2-like MADS box gene, participates in the $C$ function during stamen development in Gerbera hybrida. The Plant Cell 12: 1893-1902.

Kotilainen, M., Helariutta, Y., Mehto, M., Pöllänen, E., Albert, V.A., Elomaa, P. \& Teeri, T.H. 1999. GEG participates in the regulation of cell and organ shape during corolla and carpel development in Gerbera hybrida. The Plant Cell 11: 1093-1104.

Koutaniemi, S., Warinowski, T., Kärkönen, A., Alatalo, E., Immanen, J., Fossdal, C.G., Fagerstedt, KV, Simola, L.K., Rudd, S., Paulin, L. \& Teeri, T.H. 2007. Expression profiling of the lignin biosynthetic genes in Norway spruce using EST sequencing and quantitative real-time RT-PCR. Plant Molecular Biology, in press.

Kurkela, S., Franck, M., Heino, P., Lång, V. \& Palva, E.T. 1988. Cold induced gene-expression in Arabidopsis thaliana L. Plant Cell Reports 7: 495-498.

Laitinen, R.A.E., Broholm, S., Albert, V.A., Teeri, T.H. \& Elomaa, P. 2006. Patterns of MADS-box gene expression mark flower-type development in Gerbera hybrida (Asteraceae). BMC Plant Biology 6, article 11, doi: 10.1186/1471-2229-6-11.

Laitinen, R.A.E, Immanen, J., Auvinen, P., Rudd, S., Alatalo, E., Paulin, L., Ainasoja, M., Kotilainen, M., Koskela, S., Teeri, T.H. \& Elomaa, P. 2005. Analysis of the floral transcriptome uncovers new regulators of organ determination and gene families related to flower organ differentiation in Gerbera hybrida (Asteraceae). Genome Research 15: 475-486.

Laitinen, R.A.E., Pöllänen, E., Teeri, T.H., Elomaa, P. \& Kotilainen, M. 2007. Transcriptional analysis of petal organogenesis in Gerbera hybrida. Planta 226: 347-360.

Laurila, J., Laakso, I., Valkonen, J.P.T., Hiltunen, R. \& Pehu, E. 1996. Formation of parental-type and novel glycoalkaloids in somatic hybrids between Solanum brevidens and S. tuberosum. Plant Science 118: 145-155.

Lehtonen, M., Akita, M. \& Valkonen, J. 2006. Elicitor responses in Physcomitrella patens. MOSS 2006, University of California, Berkeley (abstr.).

Lehtonen, M.J., Ahvenniemi, P., Wilson, P.S., GermanKinnari, M. \& Valkonen, J.P.T. 2008. Biological diversity of Rhizoctonia solani (AG-3) in a northern potato cultivation environment (Fennoscandia). Plant Pathology 57: 141-151.

Lehtonen, M.J., Somervuo, P. \& Valkonen, J.P.T. 2008. Infection with Rhizoctonia solani induces defense genes and systemic resistance in potato sprouts grown without light. Phytopathology, in press.

Lehtonen, M.J., Rantala, H., Kreuze, J.F., Bång, H., Kuisma, L., Koski, P., Virtanen, E., Vihlman, K. \& Valkonen, J.P.T. 2004. Occurrence and survival of potato scab pathogens (Streptomyces species) on tuber lesions: quick diagnosis based on a PCR-based assay. Plant Pathol- ogy 53: $280-287$.

Lührs, R. \& Lörz, H. 1987. Plant regeneration in vitro from embryogenic cultures of spring-type and winter-type barley (Hordeum vulgare L.) varieties. Theoretical and Applied Genetics 75: 16-25.

Lundström, K., Salminen, M., Jalanko, A., Savolainen, R. \& Ulmanen, I. 1991. Cloning and characterization of human placental catechol-O-methyltransferase cDNA. DNA, Cell and Biology 10: 181-189.

Mäki-Valkama, T., Valkonen, J.P.T., Kreuze, J.F. \& Pehu, E. 2000. Transgenic resistance to PVYO associated with post-transcriptional silencing of $P 1$ transgene is overcome by PVYN strains that carry highly homologous $\mathrm{P} 1$ sequences and recover transgene expression at infection. Molecular Plant-Microbe Interactions 13: 366-373.

Mäkinen, K., \& Nuutila, A.M. 2004. Barley seed as a production host for industrially important proteins. AgBiotechNet 6, ABN119, 1N-8N.

Mattinen, L., Tshuikina, M., Mäe, A. \& Pirhonen, M. 2004. Identification and characterization of Nip, necrosis-inducing virulence protein of Erwinia carotovora subsp. carotovora. Molecular Plant-Microbe Interactions 17: 1366-1375.

Morel, G. \& Martin, C. 1955. Quérison de pommes de terre atteintes de maladies à virus. Comptes rendus des séances de l'Academie d'Agriculture de France, Paris $41: 472-474$.

Murashige, T. \& Skoog, F. 1962. A revised medium for rapid growth and bioassays with tobacco cell cultures. Physiologia Plantarum 15: 473-497.

Niemelä, T., Seppänen, M., Jauhiainen, L. Tulisalo, U. 2006. Yield potential of spring hybrid rape synthetics and composite hybrids compared with open-pollinated commercial cultivars. Canadian Journal of Plant Science 86: 693-700.

Paalme, V., Gammelgård, E., Järvekülg, L. \& Valkonen J.P.T. 2004. In vitro recombinants of two nearly identical potyviral isolates express novel virulence and symptom phenotypes in plants. Journal of General Virology 85: 739-747.

Pappinen, A., Degefu, Y., Syrjälä, L., Keinonen, K. \& von Weissenberg, K. 2002. Transgenic silver birch (Betula pendula) expressing sugarbeet chitinase 4 shows enhanced resistance to Pyrenopeziza betulicola. Plant Cell Reports 20: 1046-1051.

Pehu, T.M., Mäki-Valkama, T.K., Valkonen, J.P.T., Koivu, K., Lehto, K.M. \& Pehu, E. 1995. Potato plants transformed with a potato virus $Y \mathrm{P} 1$ gene sequence are resistant to PVYO. American Potato Journal 72: 523-532.

Pehu, E., Thomas, M., Poutala, T., Karp, A. \& Jones, M.G.K. 1990. Species-specific sequences in the genus Solanum: identification, characterization, and application to study somatic hybrids of $S$. brevidens and $S$. tuberosum. Theoretical and Applied Genetics 80: 693-698.

Pietarinen E. \& Seppänen, E. 1981. Start of seed potato production in Finland. Annales Agriculturae Fenniae 20: 184-187.

Pitkäjärvi, J., Räsänen, L.A., Langenskiöld, J., Wallenius, K., Niemi, M. \& Lindström, K. 2003. Persistence, population dynamics and competitiveness for nodulation of marker gene-tagged Rhizobium galegae strains in field lysimeters in the boreal climatic zone. FEMS Microbiol- 
Vol. 17 (2008): 307-324.

ogy Ecology 46: 91-104.

Pogue, G.P., Lindbo, J.A., Garger, S.A. \& Fitzmaurice, W.P. 2002. Making an ally from an enemy, plant virology and the new agriculture, Annual Review of Phytopathology 40: 45-74.

Pohjamo, M., Laaka-Lindberg, S., Ovaskainen, O. \& Korpelainen, H. 2006. Dispersal potential of spores and asexual propagules in the epixylic hepatic Anastrophyllum hellerianum. Evolutionary Ecology 20: 415-430.

Powell-Abel, P., Nelson, R.S., De, B., Hoffmann, N., Rogers, S.G., Fraley, R.T. \& Beachy, R.N. 1986. Delay of disease development in transgenic plants that express the tobacco mosaic virus coat protein gene. Science 232: 738-743.

Puurand, Ü., Valkonen, J.P.T., Mäkinen, K., Rabenstein, F. \& Saarma, M. 1996. Infectious in vitro transcripts from cloned cDNA of the potato A potyvirus. Virus Research 40: 135-140.

Rajamäki, M.L., Kelloniemi, J., Alminaite, A., Kekarainen, T., Rabenstein, F. \& Valkonen, J.P.T. 2005. A novel insertion site inside the potyvirus $\mathrm{P} 1$ cistron allows expression of heterologous proteins and suggests some P1 functions. Virology 342: 88-101.

Rajamäki, M.L., Mäki-Valkama, T., Mäkinen, K. \& Valkonen, J.P.T. 2004. Infection with potyviruses. In: Talbot, N. (ed.). Plant-Pathogen Interactions. Blackwell, Oxford, UK, p. 68-91.

Ramessar, K., Peremarti, A., Gomez-Galera, S., Naqvi, S., Moralejo, M., Munoz, P., Capell, T. \& Christou, P. 2007. Biosafety and risk assessment framework for selectable marker genes in transgenic crop plants: a case of the science not supporting the politics. Transgenic Research 16: 261-280.

Ritala, A., Aspegren, K., Kurten, U., Salmenkallio-Marttila, M., Mannonen, L., Hannus, R., Kauppinen, V., Teeri, T.H. \& Enari, T.M. 1994. Fertile transgenic barley by particle bombardment of immature embryos. Plant Molecular Biology 24: 317-325.

Ritala, A., Mannonen, L., Aspegren, K., SalmenkallioMarttila, M., Kurten, U., Hannus, R., Lozano, J.M., Teeri, T.H. \& Kauppinen, V. 1993. Stable transformation of barley tissue-culture by particle bombardment. Plant Cell Reports 12: 435-440.

Rizza, M.D., Vilaro, F.L., Torres, D.G. \& Maeso, D. 2006. Detection of PVY extreme resistance genes in potato germplasm from the Uruguayan breeding program. American Journal of Potato Research 83: 297-304.

Rokka, V.M., Pietilä, L. \& Pehu, E. 1996a. Enhanced production of dihaploid lines via anther culture of tetraploid potato (Solanum tuberosum L. ssp. tuberosum) clones. American Potato Journal 73: 1-12.

Rokka, V.M., Tauriainen, A., Pietilä, L. \& Pehu, E. 1998. Interspecific somatic hybrids between wild potato Solanum acaule Bitt. and anther-derived dihaploid potato (Solanum tuberosum L. ). Plant Cell Reports 18: 82-88.

Rokka, V.M., Valkonen, J.P.T. \& Pehu, E. 1995. Production and characterization of haploids derived from somatic hybrids between Solanum brevidens and S. tuberosum through anther culture. Plant Science 112: 85-95.

Rokka, V.M., Valkonen, J.P.T., Tauriainen, A., Pietilä, L., Lebecka, R., Zimnoch-Guzowska, E. \& Pehu, E. 2000. Production and characterization of 'second-generation' somatic hybrids derived from protoplast fusion between interspecific somatohaploid and dihaploid Solanum tuberosum L. American Journal of Potato Research 77: $149-159$.

Rokka, V.M., Xu, Y.S., Kankila, J., Kuusela, A., Pulli, S. \& Pehu, E. 1994. Identification of somatic hybrids of dihaploid Solanum tuberosum lines and Solanum brevidens by species-specific RAPD patterns and assessment of disease resistance of the hybrids. Euphytica 80: 207-217.

Rokka, V.M., Xu, Y.S., Tanhuanpää, P., Pietilä, L. \& Pehu, E. 1996b. Electrofusion of protoplasts of anther-derived dihaploid lines of commercial potato cultivars. Agricultural and Food Science in Finland 5: 499-460.

Seppänen, M.M., Cardi, T., Hyökki, M.B. \& Pehu, E. 2000. Characterization and expression of cold-induced glutathione S-transferase in freezing tolerant Solanum commersonii, sensitive $S$. tuberosum and their interspecific somatic hybrids. Plant Science 153: 125-133.

Seppänen, M.M. \& Coleman, G.D. 2003. Characterization of genotypic variation in stress gene expression and photosynthetic parameters in potato. Plant Cell and Environment 26: 401-410.

Seppänen, M.M. \& Fagerstedt, K. 2000. The role of superoxide dismutase activity in response to cold acclimation in potato. Physiologia Plantarum 108: 279-285.

Seppänen, M.M., Majaharju, M., Somersalo, S. \& Pehu, E. 1998. Freezing tolerance, cold acclimatization and oxidative stress in potato. Parauqat tolerance is related to acclimation but is a poor indicator of freezing tolerance. Physiologia Plantarum 102: 454-460.

Seppänen, S.K., Pasonen, H.L., Vauramo, S., Vahala, J., Toikka, M., Kilpeläinen, I., Setälä, H., Teeri, T.H., Timonen, S. \& Pappinen, A. 2007. Decomposition of the leaf litter and mycorrhiza-forming ability of silver birch with a genetically modified lignin biosynthesis pathway. Applied Soil Ecology 36: 100-106.

Seppänen, P., Puska, R., Honkanen, J., Tyulkina, L.G., Fedorkin, O., Morozov, S.Y. \& Atabekov, J.G. 1997. Movement protein-derived resistance to triple gene blockcontaining plant viruses. Journal of General Virology 78: 1241-1246.

Sidorov, V.A., Zubko, M.K., Kuchko, A.A., Komarnitsky, I.K. \& Gleba, Y.Y. 1987. Somatic hybridization in potato - use of gamma-irradiated protoplasts of Solanum pinnatisectum in genetic reconstruction. Theoretical and Applied Genetics 74: 364-368.

Simola, L.K. 1985. Propagation of plantlets from leaf callus of Betula pendula f. purpurea. Scientia horticulturae 26: 77-85.

Simola, L.K. \& Honkanen, J. 1983. Organogenesis and fine-structure in megagametophyte callus lines of Picea abies. Physiologia Plantarum 59: 551-561.

Simola, L.K. \& Sopanen, T. 1971. Effect of alpha-naphthaleneacetic acid and alpha-naphthoxyacetic acid on activity of certain enzymes of Atropa belladonna cv Lutea cells in suspension culture. Physiologia Plantarum 25: 8-15.

Sjöblom, S., Brader, G., Koch, G. \& Palva, E.T. 2006. Cooperation of two distinct ExpR regulators controls quorum sensing specificity and virulence in the plant pathogen Erwinia carotovora. Molecular Microbiology 60: 1474-1489.

Skarzhinskaya, M.V., Cherep, N.N. \& Gleba, Y.Y. 1982. Somatic hybridization and production of cell-lines for potato 
Elomaa, P. et al. Plant biotechnology

and tobacco plants. Tsitologiya i Genetika 16: 42-48.

Smith, N.A., Singh, S.P., Wang, M.B., Stoutjesdijk, P.A., Green, A.G. \& Waterhouse, P.M. 2000. Total silencing by intron-spliced hairpin RNAs. Nature 407: 319-320.

Snoeck, V., Cox, E., Verdonck, F., Joensuu, J.J., Goddeeris, B.M. 2004. Influence of $\mathrm{pH}$ and gastric digestion on antigenicity of F4 fimbriae for oral immunization. Veterinary Microbiology 98: 45-53.

Sønsteby, A. \& Hytönen, T. 2005. Manipulating flower induction through photoperiod and temperature fluctuations. International Journal of Fruit Science 5: 17-26.

Sorri, V.A., Watanabe, K.N. \& Valkonen, J.P.T. 1999. Predicted kinase 3 a motif of a resistance gene analogue as a unique marker for potyvirus resistance. Theoretical and Applied Genetics 99: 164-170.

Sorvari, S. 1986. Comparison of anther cultures of barley cultivars in barley-starch and agar gelatinized media. Annales Agriculturae Fenniae 25: 249-254.

Spök, A. 2007. Molecular farming on the rise - GMO regulators still walking a tightrope. Trends in Biotechnology 2: 74-82.

Stoger, E., Ma, J.K.C., Fischer, R. \& Christou, P. 2005. Sowing the seeds of success: pharmaceutical proteins from plants. Current Opinion in Biotechnology 16: 167-173.

Streatfield, S.J. 2005. Plant-based vaccines for animal health. Revue Scientifique et Technique Office International des Epizooties 24: 189-199.

Swanson, E.B., Herrgesell, M.J. Arnoldo, M., Sippell, D.W., Wong R.S.C. 1989. Microspore mutagenesis and selection: Canola plants with field tolerance to the imidazolinoes. Theoretical and Applied Genetics 78: 525-530.

Tapio, E. 1972. Virus-free clones on the potato varieties Pito and Tammiston Aikainen. Annales Agriculturae Fenniae 11: $115-118$.

Teeri, T.H. 1988. The study of gene regulation and protein targeting in plant cells using gene fusion techniques. Ph.D. thesis, University of Helsinki, Helsinki, 88 pp.

Teeri, T.H., Elomaa, P., Kotilainen, M. \& Albert, V.A. $2006 a$. Mining plant diversity: Gerbera as a model system for plant developmental and biosynthetic research. BioEssays 28: $756-767$.

Teeri, T.H., Kotilainen, M., Uimari, A., Ruokolainen, S., Ng, Y.P., Malm, U., Pöllänen, E., Broholm, S., Laitinen, R., Elomaa, P. \& Albert, V.A. 2006b. Floral developmental genetics of Gerbera (Asteraceae). Advances in Botanical Research 44: 323-351.

Teeri, T.H., Uimari, A., Kotilainen, M., Laitinen, R., Help, H., Elomaa, P. \& Albert, V.A. 2006c. Reproductive meristem fates in Gerbera. Journal of Experimental Botany 57: 3445-3455.

Tiainen, T. 1992. The influence of culture conditions on anther culture response of commercial varieties of Solanum tuberosum L. Plant Tissue and Organ Culture 30: 211-219.

Tingay, S., McElroy, D., Kalla, R., Fieg, S., Wang, M.B., Thornton, S. \& Brettell, R. 1997. Agrobacterium tumefaciens-mediated barley transformation. Plant Journal 11: 1369-1376.

Toikkanen, J.H., Niku-Paavola, M.-L., Bailey, M., Immanen, J., Rintala, E., Elomaa, P., Helariutta, Y., Teeri, T.H. \& Fagerström, R. 2007. Expression of xyloglucan endotransglycosylases of Gerbera hybrida and Betula pendula in Pichia pastoris. Journal of Biotechnolo- gy 130: 161-170.

Tommiska, J., Hämäläinen, J.H., Watanabe, K.N. \& Valkonen, J.P.T. 1998. Mapping of the gene $N x_{p h u}$ that controls hypersensitive resistance to potato virus $X$ in Solanum phureja IvP35. Theoretical and Applied Genetics 96: 840-843.

Törmälä, T., Honkanen, J. \& Seppänen, P. 1992. Potential of biotechnology in floriculture. Agro-Food-Industry Hi-tech 2: 5-8.

Truve, E., Aaspõllu, A., Honkanen, J., Puska, R., Mehto, M., Hassi, A., Teeri, T.H., Kelve, M., Seppänen, P. \& Saarma, M. 1993. Transgenic potato plants expressing mammalian 2'-5' oligoadenylate synthetase are protected from potato virus $\mathrm{X}$ infection under field conditions. Bio/Technology 11: 1048-1052.

Tuunainen, J. 2005a. Hytbrid practices? Contributions to the debate on the mutation of science and university. Higher Education 50: 275-298.

Tuunainen, J. 2005b. Contesting a hybrid firm at a traditional university. Social Studies of Science 35: 173-210.

Uimari, A., Kotilainen, M., Elomaa, P., Yu, D., Albert, V.A. \& Teeri, T.H. 2004. Integration of reproductive meristem fates by a SEPALLATA-like MADS box gene. Proceedings of the National Academy of Science USA 101: 15817-15822.

Uosukainen, M. \& Kurppa, A. 1988. Production of healthy planting material. Annales Agriculturae Fenniae 27: 209-218.

Valkonen, J.P.T. 2007. Potato viruses: economical losses and biotechnological potential. In: Vreugdenhil D., Bradshaw, J., Gebhardt, C., Govers, F., MacKerron, D.K.L., Taylor, M.A. \& Ross, H.A. 2007 (eds.). Potato Biology and Biotechnology. Elsevier, Oxford, UK, p. 619-641.

Valkonen, J.P.T., Pehu, E., Jones, M.G.K. \& Gibson, R.W. 1991. Resistance in Solanum brevidens to both potato virus $\mathrm{Y}$ and potato virus $\mathrm{X}$ may be associated with slow cell-to-cell spread. Journal of General Virology 72: 231-236.

Valkonen, J.P.T., Xu, Y.-S., Rokka, V.M., Pulli, S. \& Pehu, E. 1994. Transfer of resistance to potato leaf roll virus, potato virus $Y$ and potato virus $X$ from Solanum brevidens to $S$. tuberosum through symmetric and designed asymmetric somatic hybridization. Annals of Applied Biology 124: 351-362.

Valkonen, J.P.T., Wiegmann, K., Hämäläinen, J.H., Marczewski, W. \& Watanabe, K.N. 2008. Evidence for utility of the same PCR-based markers for selection of extreme resistance to Potato virus $Y$ controlled by $R y_{\text {sto }}$ of Solanum stoloniferum derived from different sources. Annals of Applied Biology 152: 121-130.

Van den Broeck, W., Cox, E. \& Goddeeris, B.M. 1999. Induction of immune responses in pigs following oral administration of purified F4 fimbriae. Vaccine 17: 2020-2029.

Van Molle, I., Joensuu, J.J., Buts, L., Panjikar, S., Kotiaho, M., Bouckaert, J., Wyns, L., Niklander-Teeri, V. \& De Greve, H. 2007. Chloroplast assemble FaeG the major subunit of Escherichia coli F4 (K88) fimbriae to swapped dimmers. Journal of Molecular Biology 368: 791-799.

Varrelmann, M. \& Maiss, E. 2000. Mutations in the coat protein gene of Plum pox virus suppress particle assembly, heterologous encapsidation and complementation in transgenic plants of Nicotiana benthamiana. Journal 


\section{AGRICULTURAL AND FOOD SCIENCE}

Vol. 17 (2008): 307-324.

of General Virology 81: 567-576.

Verdonck, F., Cox, E., Van der Stede, Y. \& Goddeeris, B.M. 2004. Oral immunization of piglets with recombinant F4 fimbrial adhesin FaeG monomers induces a mucosal and systemic F4-specific immune response. Vaccine 22: 4291-4299.

Vermij, P. \& Waltz, E. 2006. USDA approves the first plantbased vaccine. Nature Biotechnology 24: 233-234.

Vidal, S., Cabrera, H., Andersson, R.A., Fredriksson, A. \& Valkonen, J.P.T. 2002. Potato gene $Y$-1 is an $N$ gene homolog that confers cell death upon infection with $P_{O}$ tato virus Y. Molecular Plant-Microbe Interactions 15: 717-727.

Vreugdenhil D., Bradshaw, J., Gebhardt, C., Govers, F., MacKerron, D.K.L., Taylor, M.A. \& Ross, H.A. 2007 (eds.). Potato Biology and Biotechnology. Elsevier, Amsterdam, The Netherland, $823 \mathrm{p}$.

Wang, Q., Cuellar, W., Rajamäki, M.L., Hirata, Y. \& Valkonen, J.P.T. 2008. Combined thermotherapy and cryotherapy for virus eradication: relation of virus distribution, subcellular changes, cell survival and viral RNA degradation in shoot tips to efficient production of virus-free plants. Molecular Plant Pathology 9: 237-250.

Wang, Q. \& Valkonen, J.P.T. 2008. Efficient elimination of sweet potato little leaf phytoplasma from sweetpotato by cryotherapy of in vitro grown shoot tips. Plant Pathology 57: 338-347.

Wang, Q., Laamanen, J., Uosukainen, M. \& Valkonen, J.P.T. 2005. Cryopreservation of in vitro-grown shoot tips of raspberry (Rubus idaeus L.) by encapsulationvitrification and encapsulation-dehydration. Plant Cell
Reports 24: 280-288.

Watanabe, K.N., Orillo, M., Vega, S., Valkonen, J.P.T., Pehu, E., Hurtado, A. \& Tanksley. S.D. 1995. Overcoming crossing barriers between non tuber-bearing and tuber-bearing Solanum species: towards potato germplasm enhancement with a broad spectrum of Solanaceous genetic resources. Genome 38: 27-35.

Weaver, S.A. \& Morris, M.C. 2005. Risks associated with genetic modification: An annotated bibliography of peer reviewed natural science publications. Journal of Agricultural \& Environmental Ethics 18: 157-189.

Wenzel, G. \& Uhrig, H. 1981. Breeding for nematode and virus-resistance in potato via anther culture. Theoretical and Applied Genetics 59: 333-340

Xu, Y.S., Clark, M.S. \& Pehu, E. 1993. Use of RAPD markers to screen somatic hybrids between Solanum tuberosum and Solanum brevidens. Plant Cell Reports 12: 107-109.

Yan, Q.S., Zhang, X.Q., Shi, J.B. \& Li, J.M. 1991. Green plant regeneration from protoplasts of barley (Hordeum vulgare L.). Chinese Science Bulletin 36: 932-935.

Yu, D., Kotilainen, M., Pöllänen, E., Mehto, M., Elomaa, P., Helariutta, Y., Albert, V.A. \& Teeri, T.H. 1999. Organ identity genes and modified patterns of flower development in Gerbera hybrida (Asteraceae). Plant Journal 16: 51-62.

Zambryski P., Joos, H., Genetello, C., Leemans, J., Van Montagu, M. \& Schell, J. 1983. Ti-plasmid vector for the introduction of DNA into plant-cells without alteration of their normal regeneration capacity. EMBO Journal 2: 2143-2150. 


\title{
AGRICULTURAL AND FOOD SCIENCE
}

Elomaa, P. et al. Plant biotechnology

\section{SELOSTUS}

\section{Kasvibioteknologian tutkimus ja tulevaisuudennäkymät}

\author{
Paula Elomaa, Jussi J. Joensuu, Helena Korpelainen, Kristiina Mäkinen, Viola Niklander-Teeri, Minna \\ Pirhonen, Mervi M. Seppänen, Teemu H. Teeri ja Jari P.T. Valkonen
}

Helsingin yliopisto

Yhteyttävät kasvit ovat ravinnon ja bioenergian ensisijainen lähde maapallolla. Viljelykasvien ominaisuuksia muokkaamalla sekä kasvien biosynteesikoneistoa eri tavoin hyödyntämällä pyritään vastaamaan haasteisiin, joita väestönkasvu ja sen myötä lisääntyvä energian sekä ravinnon tarve tuovat ihmiskunnalle. Lisäksi on pyrittävä hillitsemään ilmastonmuutosta. Tämän katsauksen tarkoituksena on osoittaa, kuinka kasvibioteknologia auttaa vastaamaan näihin haasteisiin. Esimerkkeinä käytetään mm. perunan jalostukseen, viruskestävyyteen ja kylmyydensietoon sekä sädelatvan (gerberan) kukankehitykseen ja kukintaan kohdistuvaa bioteknologista tutkimusta. Se on tuottanut tietoa tärkeiden kasvigeenien sijainnista ja rakenteesta kasvigenomeissa, geenien säätelystä kehityksen aikana sekä geenien reagoinnista ympäristön muutoksiin ja taudinaiheuttajien tartuntaan. Näitä tietoja tarvitaan, jotta kasvien tuottavuutta ja kasvituotteiden laatua voidaan entisestään parantaa mm. biotekniikan keinoin. Molekyyligeneettiset tutkimukset tuottavat myös geenimerkkejä, joilla voidaan tehostaa perinteistä risteytysjalostusta. Geenitekniikan avulla on voitu kehittää uusia viruskestävyyden mekanismeja kasveihin. Biotekniikan menetelmiä voidaan hyödyntää myös syötävien rokotteiden tuottamiseen sekä farmasianteollisuuden tarvitsemien proteiinien tuotantoon kasveissa. Toisaalta biotekniikan menetelmiä tarvitaan geenivarojen kartoittamiseen sekä geneettisen monimuotoisuuden ja geenivirtojen selvittämiseen kasvipopulaatioissa. Näillä tutkimuksilla on merkitystä niin kasvien geenivarojen hyödyntämiselle kuin riskien tunnistamiselle sekä sellaisten viljelykäytäntöjen kehittämiselle, joilla voidaan ehkäistä maa- ja puutarhatalouden haittavaikutuksia viljely-ympäristön ulkopuolella. Tulevaisuudessa kasvibiotekniikalla nähdään entistä suurempi merkitys haettaessa ratkaisuja suuriin haasteisiin, jotka liittyvät ihmiskunnan selviytymiseen. Tähän tarvitaan kasvibiotekniikan osaamisen kartuttamista myös kehitysmaissa. 